\title{
INVESTIGATION OF THE RELATIONSHIP BETWEEN THE INTOLERANCE OF UNCERTAINTY AND LEVELS OF HEALTH PERCEPTION FACULTY OF SPORTS SCIENCES STUDENTS DURING THE PANDEMIC PROCESS
}

\author{
Hasan Ulukan ${ }^{\mathrm{i}}$ \\ Sport Sciences Faculty, \\ Aydin Adnan Menderes University, \\ Aydin, Turkey
}

\begin{abstract}
:
The purpose of this research examining the relationship between the level of intolerance to uncertainty and health perceptions during distance education university students and explaining whether intolerance to uncertainty predicts perception of health. This study is descriptive research in the relational survey model. The sample group consisted of 276 students, 138 (50\%) of whom were female, and 138 (50\%) of whom were male, studying distance education in the spring term of 2019-2020. Personal information form prepared by the researchers, the "Intolerance of Uncertainty Scale (IUS-12)" and "Perception of Health Scale" were used to collect data. Research data were analyzed using SPSS 25.00 statistical package program. Descriptive statistics, correlation, and statistical regression techniques were used in the analysis of the data. The significance level was determined as .05. As a result of the research, it was determined that the students' intolerance level of uncertainty was at a medium level. Their perception of health was above the medium level. It was observed that there was a low-level negative relationship between the students' intolerance to uncertainty and their perception of health. It has been determined that intolerance to uncertainty is also a low predictor of perception of health.
\end{abstract}

Keywords: Covid 19, uncertainty, intolerance of uncertainty, health, perception of health

\section{Introduction}

T.R. The Ministry of Health reported in March 2020 that the coronavirus (COVID-19) outbreak is a virus that infects people of all age groups. It has issued a precaution plan against the virus and called for action to take the necessary measures. Despite all the precautions, the virus continues its effect, and there is uncertainty about how long the epidemic, which can result in death, will last and spread. During the COVID-19 epidemic,

i Correspondence: email hasan.ulukan@adu.edu.tr; hasanulukan08@gmail.com.tr 
research on the tolerance of uncertainty and health perceptions of the entire population, especially healthcare workers and patients, is essential. This uncertain situation in the whole world is a severe illness that affects humans' health due to its prevalence during epidemics such as depression, anxiety, distress and insomnia, SARS, and COVID-19. Many studies have examined uncertainty intolerance and perception of health through demographic variables, but few studies have investigated intolerance to uncertainty during the COVID-19 pandemic concerning students' perceptions of health. The study examined intolerance to uncertainty as a determinant of students' perceptions of health during the COVID-19 pandemic. As far as we know, this study is the first to determine the perceived health status of sports sciences students and their level of intolerance to uncertainty during COVID-19.

The determination of the relationship between intolerance to uncertainty for various reasons and perception of health and whether the level of intolerance to uncertainty predicted health perception was investigated. First, the negative impact of uncertainty on humans has been more severe in the ongoing COVID-19 pandemic, suggesting that it negatively affects individuals' perception of health. Second, health research has been predicted to cause adverse psychological disorders in humans with the continuation of the COVID-19 pandemic. Third, a high perception of health can reduce individuals' chances of good health affected by the COVID-19 virus. Fourth, the continuation of uncertainty may help determine whether individuals' perceptions of health are negatively affected by the decrease in people's tolerance to this uncertainty. Finally, health perception status is a subjective indicator that can be reliably, quickly, and cost-effectively applied in evaluating population groups' health perceptions (AguilarPalacio ve ark., 2015; Lima ve ark., 2004). Perception of health includes physical, cognitive, and emotional components and aspects related to one's own life's well-being and satisfaction (Pagotto ve ark., 2013; Pavao ve ark., 2013; Melo ve ark., 2017). For this reason, individuals' perceptions of health may have been negatively affected during the uncertain COVID-19 epidemic. The predictions were tested on distance education students at Aydın Adnan Menderes University in the departments of coaching, physical education, and sports education, recreation, and sports management with the help of appropriate scales.

\section{Problem Sentence/Question}

1) Is there a relationship between the level of intolerance to uncertainty and perceptions of students' health studying at the sports sciences faculty?

\subsection{Sub Problem Sentences/Questions}

Students studying at the faculty of sports sciences:

1) How is the level of uncertainty intolerance?

2) How is the level of perception? 
3) How is the level of uncertainty, intolerance, and perception of health according to gender?

4) Is the intolerance of uncertainty variable a predictor of the health perception variable?

\section{The Importance of This Study}

Health perceptions play an important role in people's coping with health problems. In this case, it has been reported that students' perception of their health status positively affects their beliefs about controlling their future health status and healthy lifestyle behaviors (Zaybak \& Fadıloğlu, 2004). During the COVID 19 epidemic, which preserved its state of uncertainty, it has been a question of whether the illnesses such as depression, anxiety, distress, and insomnia experienced by individuals in the face of this situation affect their perception of health. In this regard, students' intolerance to uncertainty and their perception of health were examined. The uncertainty, anxiety, and thoughts of the students towards the future will cause them to lose their positive psychology, self-esteem, life expectancy, and thus their perception of health will be negatively affected. This study about this situation aimed to determine the relationship between two variables and investigate whether intolerance to uncertainty predicts health perception to improve awareness.

\section{Literature Review}

\subsection{Intolerance of Uncertainty}

Human beings maintain their lives in a world where they do not know what to live and what to face. In this respect, uncertainty as a concept brought about by the unknown about the future is a phenomenon that people have to face every minute (Bozkurt, 2019). Uncertainty: the situations that we encounter for the first time and feel unfamiliar may occur in three different ways, such as complicated situations where we are exposed to more than one factor and unstable situations where the clue, we have indicated different information (Stanley Budner, 1962). The concept of uncertainty, which is also expressed as being unsure of the future, is also defined as not knowing what the outcome of an event and any behavior will be and can negatively affect human psychology (Çardak, 2012; Sarıçam et al., 2014). Uncertainty occurs when perceptions and behaviors do not respond appropriately to unexpected situations. This situation decreases the ability to do things right (Jeong-Sook, 2018). Kasperson (2008) defines uncertainty as a situation in which the direction of change is relatively well known, but the importance of events and their consequences cannot be predicted with any prediction of their probability of occurrence.

The concept of intolerance to uncertainty, which is defined as an individual's tendency to find the possibility of an adverse event occurring extremely unacceptable 
(Dugas et al., 2001), was first addressed as the theme of generalized anxiety disorder. In common anxiety, the person's anxiety does not gather around a specific theme and becomes generalized (Robichaud \& Dugas, 2015). Intolerance to uncertainty is expressed as a tendency to react negatively cognitively, emotionally, and behaviorally, which consists of false beliefs that uncertain situations will lead to negative consequences, the tendency to perceive uncertain situations as a source of danger, and biases accompanied by erroneous evaluations (Dugas et al., 2004; Freeston et al., 2004; Freeston et al., 1994; Stanley Budner, 1962). It has been suggested that people's predisposition to perceive uncertain situations as dangers is to be aware of what will happen to them in human nature and to ensure their future lives (Grenier et al., 2005).

Intolerance to uncertainty, which tends to exhibit negative thoughts about the uncertain situation and its connotations and possible consequences, was considered an element of cognitive predisposition and conceptualized as a unique feature. In this context, it was thought that people with high cognitive predisposition were more prone to show certain cognitive biases. Therefore, it was argued that intolerance to uncertainty itself was the factor that led to the interpretation of ambiguous situations as dangerous or harmful (Koerner \& Dugas, 2006; Korner \& Dugas, 2008).

Intolerance to uncertainty expressed simply as adverse reactions to uncertainty (Carleton et al., 2012), is defined by Laing (2015) as the form of anxiety an ontologically insecure person faces. According to him, the individual who tries to struggle with uncertainty first defends against the uncertain situation to prove his existence and experiences fear of extinction. Later, he realizes that this is meaningless and accepts that he exists and is real in uncertainty. Finally, he accepts both the uncertainty of his situation and his existence and continues his life.

It has been stated that people with a high intolerance to uncertainty have pessimistic predictions about future distressing and stressful life events, tend to see uncertain events negatively, and avoid uncertainty more than other people (Buhr and Dugas 2002).

\subsection{Perception of Health}

Health is a condition that individuals define in terms of their values. Health is a dynamic process in which individuals maintain their well-being by adapting to changes in their internal and external environments (Bayat, 2012; WHO, 2020). It was made by the World Health Organization (WHO) and defined as "not only the absence of illness or disability but also a state of complete physical, social and mental well-being." "Complete well-being" in this definition of health, which is the most widely known, means meeting the needs fully. Individuals' definitions of health are essential in realizing health-enhancing behaviors (Öz, 2004; Tillet \& Pender, 1998; Pender et al., 2006). Being healthy is one of the fundamental human rights. Today's health policies, which are based on the protection, maintenance, and development of this right, focus on individuals taking their health 
responsibility and gaining behaviors that will improve their health (Ayaz et al., 2005; Kang, 1995).

Perception of health is defined as evaluating one's health status (American Thoracic Society). Individual's positive beliefs about his own health "good health"; carrying negative beliefs is called "perception of bad health" (Ağaçdiken Alkan et al., 2017). Positive health perception is essential for individuals to gain healthy lifestyle behaviors. Perception of health is directly related to the health promotion process, which aims to acquire and maintain health-enhancing life behaviors (Klein et al., 2010). In other words, perception of health refers to individuals' feelings about their health. These feelings are associated with behaviors such as feeling good, eating healthy, and avoiding harmful habits. These behaviors may vary from past to present, from society to society. Variations can be seen between different age groups in the same society (Çalışkan et al., 2018).

The way of perceiving health is based on individuals' evaluations of their health conditions in general and is a simple but powerful indicator that reflects the multidimensionality of health and enables the individual to evaluate his / her biological, mental, and social situation (Tuğut \& Bekar, 2008). The perception of health is the general expression of individuals' feelings, thoughts, concerns, prejudices, and expectations regarding their health. Individuals describe their health status as good or bad, and their perceptions of health, according to their subjective expressions, affect their health protection and development behaviors and self-care management (Durmaz et al., 2020). Many conceptual models (such as the health belief model and social learning model) have been developed to clarify the formation of health behaviors that affect the health status of the individual and how these behaviors can be changed (Kadioğlu \& Yıldız, 2012). According to the health belief model, the perception of health status affects health behaviors and health responsibility. Consequently, the perception of health is directly associated with the health promotion process that aims to provide individuals with healthy lifestyle behaviors and maintain these behaviors at the level of health protection (Bottorff et al., 1996).

\section{Material and Methods}

\subsection{Model of Research}

Since the research aims to explain the relationship between two or more variables, it was designed in a relational survey model in quantitative research design (Karasar, 2009). Studies conducted in the scanning model are studies that try to explain the characteristics of large masses (Büyüköztürk et al., 2012). In this study, the relationship between intolerance to uncertainty and students' health perception studying at the faculty of sports sciences was examined. In this respect, the study displays the features of the relational screening model. The study also examined whether intolerance to uncertainty predicted the perception of health. 


\subsection{Population of the Study}

Students studying at Aydin Adnan Menderes University Faculty of Sport Sciences constituted the universe of the research. The study sample was created according to the convenience sampling method, starting with the easiest to reach participants. Büyüköztürk et al. (2012), the appropriate sampling method is the sampling method in which the sampling is completed, starting with the easiest to reach participants in order to reach the required number of participants in the study. The study sample consisted of 276 students, 138 (50\%) female, and 138 (50\%) male. The average age of the students participating in the study was calculated as $(21.12+2.42)$.

\subsection{Data Collection Tools}

\subsubsection{Intolerance of Uncertainty Scale (IUS-12)}

The Turkish adaptation study of the scale developed by Carleton, Norton, and Asmundson (2007) was carried out by Sarıçam et al. (2014). The scale was developed with a scale match for students' intolerance to uncertainty. The Intolerance to Uncertainty Scale (IUS-12) consists of 2 sub-dimensions and 12 questions. The sub-dimensions of the scale are "forward anxiety" and "preventive anxiety." This study was evaluated according to the score obtained from the overall scale. The total score that can be obtained from the scale varies between 12 and 60. The scale, which is in the five-point Likert type, is graded as "1" Not suitable for me at all - "5" entirely suitable for me. Increasing scores indicate an increase in intolerance to uncertainty (Sarıçam et al., 2014). The Cronbach alpha internal consistency reliability coefficient of the IUS-12 was .88 for the whole scale. For this study, the Cronbach Alpha internal consistency reliability coefficient was calculated as .80 .

\subsubsection{Perception of Health Scale}

The scale was developed by Diamond et al. (2007) and adapted into Turkish by Kadığlu and Yildiz (2012). The scale is a five-point Likert-type scale consisting of 15 items and four sub-factors. The sub-factors of the scale are "control center," "certainty," "the importance of health," "self-awareness." Items 1, 5, 9, 10, 11 and 14 are positive attitude, items 2, 3, 4, 6, 7, 8, 12, 13 and 15 are negative statements. . Positive statements were scored as "strongly agree $=5$ ", "agree $=4$ ", "indecisive $=3$ ", "disagree $=2$ ", "strongly disagree $=1 "$. Negative statements were scored inversely. The minimum score that can be obtained from the scale is 15 , and the highest score is 75 . In this study, the evaluation was made according to the average score obtained from the overall scale. The Cronbach Alpha of the scale is 0.77. For this study, the Cronbach Alpha internal consistency coefficient was calculated as 0.71 .

\subsection{Data Analysis}

The data of the research were analyzed using the SPSS 25.00 statistical package program. When testing the research data, a significance level of 0.05 was taken. Frequency (f), percentage $(\%)$, and weighted average $(\bar{x})$ values were used in the analysis of the 
descriptive data obtained. In analyzing the data, correlation analysis is used to determine the relationship between intolerance to uncertainty and perception of health; Simple regression analysis was performed to determine whether intolerance to uncertainty predicted health perception. Also, descriptive statistics were used to determine the students' level of intolerance to uncertainty and perception of health.

\section{Results}

Table 1: Frequency and Percentage Analysis of Participants' Demographic Information

\begin{tabular}{|c|c|c|c|c|c|c|c|}
\hline & & \multicolumn{2}{|c|}{ Female } & \multicolumn{2}{|c|}{ Male } & \multicolumn{2}{|c|}{ Total } \\
\hline & & $f$ & $\%$ & $f$ & $\%$ & $\mathrm{f}$ & $\%$ \\
\hline \multirow{4}{*}{ 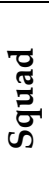 } & Coaching & 47 & 34,1 & 39 & 28,3 & 86 & 31.2 \\
\hline & Physical Education and Sports Education & 36 & 26,1 & 12 & 8,7 & 48 & 17.4 \\
\hline & Sports Management & 28 & 20,3 & 50 & 36,2 & 78 & 28.3 \\
\hline & Recreation & 27 & 19,6 & 37 & 26,8 & 64 & 23.2 \\
\hline
\end{tabular}

In the study, students' levels of intolerance to uncertainty and perception of health were analyzed using descriptive statistical analysis, and the analysis results are given in Table 2.

Table 2: Participants' Intolerance to Uncertainty and Perception of Health Levels

\begin{tabular}{lccccccc}
\hline & \multicolumn{2}{c}{ Female } & \multicolumn{2}{c}{ Male } & \multicolumn{3}{c}{ Total } \\
\cline { 2 - 9 } & $\mathbf{n}$ & $\overline{\mathbf{x}}$ & $\mathbf{n}$ & $\overline{\mathbf{x}}$ & $\mathbf{n}$ & $\overline{\mathbf{x}}$ & sd \\
\hline Intolerance of uncertainty & 138 & 40.03 & 138 & 40,56 & 276 & 40,29 & 7,99 \\
\hline Perception of health & 138 & 52,75 & 138 & 55,53 & 276 & 54,94 & 7,38 \\
\hline
\end{tabular}

In Table 2, it was determined that the intolerance level of the students participating in the research was at a medium level $(\overline{\mathrm{x}}=40.29 ; \mathrm{Sd}=7.99)$. Students' perception of health was found to be above the middle level $(\bar{x}=54.94 \mathrm{Sd}=7.38)$. As a result of the average score obtained by gender in the study, it was found that the levels of intolerance to uncertainty $(\bar{x}=40.56)$ and perception of health $(\bar{x}=55.53)$ of men were higher than women's levels of intolerance to uncertainty $(\bar{x}=40.03)$ and perception of health $(\bar{x}=52.75)$.

In the study, the relationship between students' intolerance to uncertainty and perception of health was examined by simple partial correlation analysis, and the analysis results are given in Table 3.

Table 3: The Relationship Between Intolerance to Uncertainty and Perception of Health

\begin{tabular}{lllc}
\hline & & Perception of health \\
\hline Intolerance of uncertainty & $\mathrm{r}$ &,$- 153^{*}$ \\
\cline { 2 - 4 } & $\mathrm{p}$ & .011 \\
\hline
\end{tabular}

${ }^{*} \mathrm{p}<.05$ 
When Table 3 is examined, it is seen that there are significant relationships between variables. A low level of significant negative correlation was found between intolerance to uncertainty and health perception $(\mathrm{r}=-.153, \mathrm{p}<.05)$.

The results of simple regression analysis to examine the predictive role of intolerance to health perception are given in Table 4.

Table 4: Simple Regression Analysis Results Related to the Prediction of Perception of Health by Intolerance to Uncertainty

\begin{tabular}{lccccccc}
\hline & $\mathbf{B}$ & Standard error & $\boldsymbol{\beta}$ & $\mathbf{t}$ & $\mathbf{p}$ & $\mathbf{R}$ & $\mathbf{R}^{2}$ \\
\hline Constant & 59.628 & 2.266 & & 26.314 & .000 & .153 & .023 \\
\hline Intolerance of Uncertainty & -.141 & .055 & -.153 & -2.560 & .011 & & \\
\hline
\end{tabular}

$\mathrm{F}=6.552 * \mathrm{p}<.05$

When Table 4 is examined, it is seen that intolerance to uncertainty scores $(R=.153$, $\left.\mathrm{R}^{2}=.023, \mathrm{~F}=6.552, \mathrm{p}<.05\right)$ significantly predict health perception levels. In this case, intolerance to uncertainty explains $2.3 \%$ of the variance regarding health perception levels. According to the standardized regression coefficient $(\beta)$, the contribution of intolerance to uncertainty in predicting the level of perception of health was found to be statistically significant $(\beta=-.153, \mathrm{t}=-2.560, \mathrm{p}<.05)$.

\section{Discussion and Conclusion}

This study tried to examine the relationship between intolerance to uncertainty and health perception levels of students studying at Aydin Adnan Menderes University Faculty of Sport Sciences and to explain whether intolerance to uncertainty predicted the perception of health. Also, it aimed to determine the level of intolerance to uncertainty and perception of students' health.

It was determined that the intolerance of uncertainty level of the students participating in the study was moderate, and the average score of intolerance of the uncertainty of males was higher than that of female students. In this case, it can be said that sports science faculty students are disturbed by uncertain situations, anxious, stressed, and lose their belief that they are right when they are not sure of their goals. Thus, it can be concluded that uncertainty prevents them when they want to act in line with their goals. When individuals have a high intolerance to uncertainty; It can be observed that individuals tend to perceive uncertain situations as unpleasant and stressful situations, avoid uncertainty, and experience disruption in their functionality in situations involving uncertainty (Buhr \& Dugas, 2002). As a result of the research conducted by Duman (2020) on university students, it was observed that the participant group had a moderate intolerance to uncertainty. As a result of their research on university students, Gecgin and Sahranc (2017) found that women have higher levels of intolerance to uncertainty than men. Karataş and Uzun (2018) concluded in their study on university students that women have a higher level of intolerance to uncertainty than 
men. A different study conducted on university students observed that the average score of the students' intolerance to uncertainty was at a moderate level (Bozkur et al., 2020). Ulukan and Esenkaya (2020), as a result of their study investigating the intolerance of uncertainty among university students, found that men had higher levels of anxiety towards the future and preventive anxiety than women. As a result of the study in which B1kmaz and Akça-Yağan (2020) examined the intolerance of senior university students' uncertainty levels, it was determined that men were more disturbed by the uncertainty about the future than women. As a result of their research, Barahmand et al. (2014) stated that $16.7 \%$ of males and $7.7 \%$ of females are incredibly intolerant of uncertainty.

It was found that the health perception levels of the students participating in the study were above the middle level. Besides, it was observed that the average scores of the perception of male students' health were higher than that of women. It is thought that students' perception of health is above the middle level; they attach importance to their health and lead a healthy life with exercise and proper nutrition. Individuals' perceptions affect their health behaviors (Souto et al., 2018). In the literature review, it is seen that the studies generally focus on medical and nursing students. In the study conducted by Özdelikara et al. (2018) on nursing students, it was concluded that students' perceptions of health were at medium levels. Yalnızoğlu-Çaka et al. (2017) analyzed the relationship between nursing students 'perception of health and self-confidence and found that students' perceptions of health were above the average. Similarly, as a result of other studies conducted to determine the health perceptions of nursing students, it was found that students' perception of health was at a moderate level (Açıksöz et al., 2013; Çilingir \& Aydın, 2017; Ağaçdiken-Alkan et al., 2017). Eser et al. (2012), as a result of the study, conducted to evaluate the health perception levels of the students of the faculty of pharmacy, it was observed that the students' perception level of health was at a moderate level. A different study examining university students' health perception determined that students perceived their health status as good (Tuğut \& Bekar, 2008). In another study, factory employees' health perception levels were examined, and it was determined that the employees' health perception levels were at a moderate level (Kolaç et al., 2018).

A low level of significant negative correlation was found between intolerance to uncertainty and perception of health. This means that as the students' intolerance to uncertainty increases, their perception of health decreases. In the literature review, no study directly examining the perception of health and intolerance to uncertainty was found. It can be said that psychological well-being is an indicator of mental health and general well-being. Kasapoğlu (2020) found a moderate negative relationship between intolerance to uncertainty and psychological resilience as a result of his research on adult individuals. As a result of his research on students at different universities, Erguvan (2015) found a significant negative relationship between intolerance to uncertainty and psychological well-being. The total psychological well-being level of university students with a high level of intolerance to uncertainty is lower (Gecgin \& Sahranc, 2017). Intolerance to uncertainty is associated with various problems such as depression, panic, 
anxiety, and low quality of life (Barahmand \& Haji, 2014; Carleton et al., 2010; Carleton et al., 2014; Yook et al., 2010). The findings are in line with the results of our study.

In the study, it is seen that intolerance to uncertainty significantly predicts perception of health levels. Intolerance to uncertainty explains $2.3 \%$ of the change in the level of perception of health. According to the t-test results regarding the regression coefficients' significance, intolerance to uncertainty was a significant predictor of health perception. In this case, health promotion, which is a predictor of intolerance to uncertainty, is essential. Appropriate strategies and tools for health promotion should be used.

\section{Conclusion}

As a result of the study examining whether the levels of intolerance to the uncertainty of students of sports sciences to predict their perception of health, it was determined that students 'intolerance to uncertainty was a significant predictor of health perception and that there was a low level of negative correlation between students' intolerance to uncertainty and their health perception. In the study, the intolerance of uncertainty and health perception levels of the students of the faculty of sports sciences were examined separately, and as a result, it was found that the students' intolerance level of uncertainty was moderate, and their health perception level was above the middle level. Also, it was determined that the average scores of intolerance to uncertainty and perception of male students' health were higher than female students.

\section{Limitations}

This study is limited to 1. and 2. grade students in the Departments of Coaching, Physical Education and Sports Education, Recreation and Sports Management at Aydin Adnan Menderes University Sports Sciences Faculty year 2020-2021.

\section{Recommendations}

In order to increase the intolerance level of students against uncertainty, their future anxieties can be removed, or their level of perception of health can be increased. To minimize uncertain situations that prevent students from focusing on the goal, appropriate studies can be determined to strengthen them physically, mentally, and psychologically. Also, researches can be conducted to determine and eliminate other factors that cause an increase in the level of intolerance to uncertainty.

\section{Conflict of Interest Statement}

The authors declare no conflicts of interests. 


\begin{abstract}
About the Author
Hasan Ulukan graduated from Niğde University, Faculty of Sport Sciences, Department of Physical Education and Sports in 2003. Between 2010-2012, he completed his master's degree at Karamanoğlu Mehmetbey University, Institute of Social Sciences, Department of Physical Education and Sports Education. He completed his doctorate at Sakarya University, Institute of Educational Sciences, Department of Physical Education, and Sports Education. He is currently working at Aydın Adnan Menderes University, Faculty of Sport Sciences.
\end{abstract}

\title{
References
}

Açıksöz, S., Uzun, Ş., Arslan, F. (2013). Hemşirelik öğrencilerinin sağlık algısı ile sağlığı geliştirme davranışları arasındaki ilişkinin incelenmesi [Relationship between perceptions of health status and health promotion behaviors in nursing students]. Gülhane Medical Journal / Gülhane Tip Dergisi, 55, 181-187. https://doi.org/10.5455/gulhane.15228

Ağaçdiken-Alkan, S., Özdelikara, A., Mumcu-Boğa, N. (2017). Hemşirelik öğrencilerinin sağlık algılarının belirlenmesi [Determination of nursing students' health perception]. Gümüşhane University Journal of Health Sciences / Gümüşhane Üniversitesi Sağlik Bilimleri Dergisi, 6(2), 11-21. https://doi.org/10.5350/BTDMJB.20170310015347

Aguilar-Palacio, I., Carrera-Lasfuentes, P., Rabanaque, M. J. (2015). Salud percibida y nivel educativo en España: tendencias por comunidades autónomas y sexo (20012012) [Self-rated health and educational level in Spain: Trends by autonomous communities and gender (2001-2012)]. Gaceta Sanitaria, 29(1), 37-43. https://doi.org/10.1016/j.gaceta.2014.07.004

American Thoracic Society (ATS) (2020). Health Status, Health Perceptions. Retrieved from: $\quad$ https://qol.thoracic.org/sections/key-concepts/health-status-healthperceptions.html

Ayaz, S., Tezcan, S., Akıncı, F. (2005). Hemşirelik yüksekokulu öğrencilerinin sağlı̆̆ı geliştirme davranışları [Health promotion behavior of nursing school students]. Journal of Cumhuriyet University School of Nursing / Cumhuriyet Üniversitesi Hemşirelik Yüksek Okulu Dergisi, 9(2), 26-34.

Barahmand, U. \& Haji, A. (2014). The impact of intolerance of uncertainty, worry and irritability on quality of life inpersons with epilepsy: Irritability as mediator. Epilepsy Research, 108(8), 1335-1344. https://doi.org/10.1016/j.eplepsyres.2014.07.002

Barahmand, U., Shahbazi, Z., \& Kalatari, P. (2014). Prevalence of obsessive belief and intolerance of uncertainty among college student. The Neuroscience Journal of Shefaye Khatam, 2(3), Suppl 1, P69. 
Bayat, M. (2012). Să̆lık ve hastalık: Kültürlerarası hemşirelik [Health and Disease: Intercultural Nursing]. Istanbul Tip Kitapevi.

Bıkmaz, Z., Akça-Yağan, N. (2020). Üniversite son sınıf öğrencilerinin iş bulma kaygısı ve belirsizliğe tahammülsüzlük düzeylerinin incelenmesi [Analysis of university senior students' levels of anxiety and intolerance of uncertainty to regarding job finding]. Pearson Journal of Social Sciences \& Humanities, 5(8), 169-181. https://dx.doi.org/10.46872/Pj.161

Bottorff, J. L., Johnson, J. L., Ratner, P. A., Hayduk, L. A. (1996). The effects of cognitiveperceptual factors on health promotion behavior maintenance. Nursing Research 45(1), 30-36. https://doi.org/10.1097/00006199-199601000-00006

Bozkur, B., Kıran, B., \& Cengiz, Ö. (2020). Üniversite öğrencilerinin umutsuzluk, belirsizliğe tahammülsüzlük, gelecekte iş bulmaya yönelik algı ve özyeterliklerinin incelenmesi [The examination of college students' hopelessness, intolarence of uncertainity, perception towards finding a job and self-eficacy]. Kastamonu Education Journal / Kastamonu Eğitim Dergisi, 28(6), 2401-2409. https://doi.org/10.24106/kefdergi.702233

Bozkurt, T. (2019). Üniversite öğrencilerinin otantiklik, sosyal bağhllık ve belirsizliğe tahammülsüzlük özelliklerinin sakin benlik düzeylerini yordayıcılı̆̆ı [Predictability of university students' authenticity, social connectedness and intolerance of uncertainty on quite ego levels]. Master's Thesis. Anadolu University, Institute of Educational Sciences, Guidance and Psychological Counseling Program, Educational Sciences Department, Eskişehir.

Buhr, K., \& Dugas, M. J. (2002). The intolerance of uncertainty scale: Psychometric properties of the english version. Behaviour Research and Therapy, 40(8), 931-945. https://doi.org/10.1016/S0005-7967(01)00092-4

Büyüköztürk, Ş., Akgün, E., Kılıç-Çakmak, E., Demirel, F., \& Karadeniz, Ş. (2012). Bilimsel araştırma yöntemleri [Scientific research methods]. (11. edition). Pegem A Yayınları. https://doi.org/10.14527/9789944919289

Çalışkan, S., Aydoğan, S., Işıklı, B., Metintaş, S., Yenilmez, F., Yenilmez, Ç. (2018). Üniversite öğrencilerinde algılanan stres düzeyi ve ilişkili olabilecek faktörlerin değerlendirilmesi [Assessment of perceived stress level and related factors in university students]. Türk Dünyası Uygulama ve Araştırma Merkezi Halk Sağhı̆̆ı Dergisi, 3(2), 39-49.

Çardak, M. (2012). Affedicilik yönelimli psiko-eğitim programının affetme eğilimi, belirsizliğe tahammülsüzlük, psikolojik iyi oluş, sürekli kaygı ve öfke üzerindeki etkisinin incelenmesi [Investigation of the effects of the psycho-education curriculum to enhance the tendency of forgiveness on intolerance to uncertainty, psychological well-being, persistent anxiety and anger]. Ph.D. Thesis, Sakarya University, Institute of Educational Sciences, Department of Educational Sciences, Division of Psychological Services in Education, Sakarya. 
Carleton. R. N., Duranceau, S., Freeston, M. H., Boelen, P. A., McCabe, R. E. \& Antony, M. M. (2014). But it might be a heart attack: Intolerance of uncertainty and panic disorder symptoms. Journal of Anxiety Disorders, 28(5), 463-470. https://doi.org/10.1016/j.janxdis.2014.04.006

Carleton. R. N., Weeks, J. W., Howell, A. N., Asmundson, G. J., Antony, M. M., McCabe, R. E. (2012). Assessing the latent structure of the intolerance of uncertainty construct: An initial taxometric analysis. Journal of Anxiety Disorders, 26(1): 150-157. https://doi.org/10.1016/j.janxdis.2011.10.006

Carleton, R. N., Collimore, K. C. \& Asmundson, G. (2010). It's not just the judgmentsIt's that I don't know: Intolerance of uncertainty as a predictor of social anxiety. Journal of Anxiety Disorders, 24(2), 189-195. https://doi.org/10.1016/j.janxdis.2009.10.007

Carleton, R. N., Norton, M. P. J., \& Asmundson, G. J. (2007). Fearing the unknown: A short version of the Intolerance of Uncertainty Scale. Journal of Anxiety Disorders, 21(1), 105-117. https://doi.org/10.1016/j.janxdis.2006.03.014

Çilingir, D. \& Aydın, A. (2017). Hemşirelik bölümünde öğrenim gören öğrencilerin sağlık alg1s1 [Department of Nursing Students' Perception of Health]. FNJN Florence Nightingale Hemşirelik Dergisi / FNJN Florence Nightingale Journal of Nursing, 25(3): 167-176. https://doi.org/10.17672/fnjn.343254

Diamond, J. J., Becker, J. A., Arenson, C. A, Chambers, C. V., Rosenthal, M. P. (2007). Development of a scale to measure adults' perceptions of health: priliminary findings. Journal of Community Psychology, 35(5), 557-561. https://doi.org/10.1002/jcop.20164

Dugas, M. J., Schwartz, A., Francis, K. (2004) Brief report: intolerance of uncertainty, worry, and depression. Cognitive Therapy and Research 28(6), 835-842. https://doi.org/10.1007/s10608-004-0669-0

Dugas, M. J., Buhr, K., \& Ladouceur, R. (2004). The role of intolerance of uncertainty in etiology and maintenance. In R. G. Heimberg, C. L. Turk, \& D. S. Mennin (Eds.), Generalized anxiety disorder: Advances in research and practice (p. 143-163). The Guilford Press.

Dugas, M. J., Gosselin, P., \& Ladouceur, R. (2001). Intolerance of uncertainty and worry: Investigating specificity in a nonclinical sample. Cognitive Therapy and Research, 25(5), 551-558. https://doi.org/10.1023/a:1005553414688

Duman, N. (2020). Üniversite öğrencilerinde covid-19 korkusu ve belirsizliğe tahammülsüzlük [Covıd-19 Fear and intolerance to uncertainty in university students]. The Journal of Social Science, 4(8), 426-437. https://doi.org/10.30520/tjsosci.748404

Durmaz, S., Sürücü, E. \& Özvurmaz, S., (2020). Mermer Fabrikası İşçilerinde Sağlık Okuryazarlığı, Sağlık Algısı Düzeyleri ve İlişkili Faktörlerin Belirlenmesi [Determination of health literacy, health perception levels and related factors of 
INVESTIGATION OF THE RELATIONSHIP BETWEEN THE INTOLERANCE OF

UNCERTAINTY AND LEVELS OF HEALTH PERCEPTION FACULTY OF SPORTS SCIENCES STUDENTS DURING THE PANDEMIC PROCESS

marble factory workers]. Medical Sciences (NWSAMS), 15(3), 81-91. https://doi.org/10.12739/NWSA.2020.15.3.1B0092

Erguvan, F. M. (2015). Üniversite Öğrencilerinin Belirsizliğe Tahammülsüzlük Düzeyleri İle Psikolojik Iyi Olma Düzeylerinin İncelenmesi [An examination of intolerance of uncertainty levels and psychological well-being levels of university students]. Master Thesis, Sakarya University, Institute of Educational Sciences, Department of Educational Sciences, Division of Psychological Services in Education, Sakarya.

Eser, S., İkinci, S., Ocaktan, M. E., Çalışkan, D., Piyal, B., Akdur, R. (2012). Eczacıllk Fakültesi öğrencilerinde sağlık algısının değerlendirilmesi [Evaluation of health

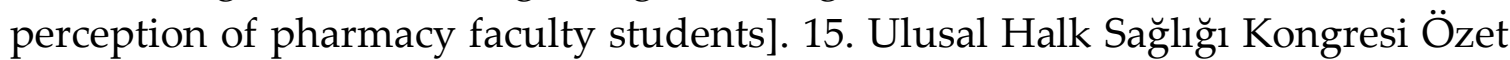
Kitab1 / 15. National Public Health Congress Book, 2-6 Ekim, 592-594.

Freeston, M. H., Rhéaume, J., Letarte, H., Dugas, M. J., \& Ladouceur, R. (1994). Why do people worry? Personality and Individual Differences, 17(6), 791-802. https://doi.org/10.1016/0191-8869(94)90048-5

Geçgin, F. M. \& Sahranç, Ü. (2017). Belirsizliğe tahammülsüzlük ile psikolojik iyi oluş arasındaki ilişki [The relationships between intolerance of uncertainty and psychological well-being]. Sakarya University Journal of Education, 7(Special Issue 4), 739-755. https://doi.org/10.19126/suje.383737

Grenier, S., Barrette, A. M., \& Ladouceur, R. (2005). Intolerance of uncertainty and intolerance of ambiguity: Similarities and differences. Personality and Individual Differences, 39(3), 593-600. https://doi.org/10.1016/j.paid.2005.02.014

Jeong-Sook, L. (2018). Effect of Resilience On İntolerance of Uncertainty İn Nursing University Students, Nursing Forum, 58(2), 1-7. https://doi.org/10.1111/nuf.12297

Kadıŏlu, H., Yıldız, A. (2012). Sağlık Algısı Ölçeği'nin Türkçe Çevriminin Geçerlilik ve Güvenilirliği [Validity and Reliability of Turkish Version of Perception of Health Scale]. Turkiye Klinikleri Journal of Medical Sciences, 32(1), 47-53. https://doi.org/10.5336/medsci.2010-21761

Kang, R. (1995). Building community capacity for health promotion: A challenge for public health nurses. Public Health Nursing, 12(5), 312-318. https://doi.org/10.1111/j.1525-1446.1995.tb00154.x

Karasar, N. (2009). Bilimsel araştırma yöntemleri [Scientific research methods]. Nobel Yayınları.

Karataş, Z. \& Uzun, K. (2018). Belirsizliğe tahammülsüzlüğün yordayıcısı olarak endişe ile ilgili olumlu ve olumsuz inançlar [Positive and negative beliefs about worry as the predictors of intolerance of uncertainty]. Kastamonu Education Journal, 26(4), 1267-1276. https://doi.org/10.24106/kefdergi.434169

Kasapoğlu, F. (2020). COVID-19 salgını sürecinde kaygı ile maneviyat, psikolojik sağlamlık ve belirsizliğe tahammülsüzlük arasındaki ilişkilerin incelenmesi [Examination of the relationship between anxiety with spirituality, resilience and intolerance of uncertainty in the COVID-19 outbreak process]. Turkish Studies, 15(4), 599-614. https://dx.doi.org/10.7827/TurkishStudies.44284 
Kasperson, R. E. (2008). Coping with Deep Uncertainty: Challenges for Environmental Assessment and Decision-Making. In G. Bammer \& M. Smithson (Ed.). Uncertainty and Risk: Multidisciplinary Perspectives. London, Cromwell Press. https://doi.org/10.4324/9781849773607

Klein-Velderman, M., Crone, M. R., Wiefferink, C. H., Reijneveld, S. A. (2010). Identification and management of psychosocial problems among toddlers by preventive child health care professionals. European Journal of Public Health, 20(3), 332-338. https://doi.org/10.1093/eurpub/ckp169

Koerner, N. \& Dugas, M. J. (2006). A cognitive model of generalized anxiety disorder: The role of intolerance of uncertainty. Worry and its psychological disorders: Theory, Assessment and Treatment, 201-216. https://doi.org/10.1002/9780470713143.ch12

Koerner N. \& Dugas M. J. (2008). An Investigation of appraisals in individuals vulnerable to excessive worry: the role of intolerance of uncertainty. Cognitive Therapy and Research, 32(2): 619-638. https://doi.org/10.1007/s10608-007-9125-2

Kolac, N., Balci, A. S., Sisman, F. N., Atacer, B. E., Dincer, S. (2018). Health perception and healthy lifestyle behaviors in factory workers. The Medical Journal of Bakırköy / Bakırköy Tip Dergisi, 14(3), 267-274. https://doi.org/10.5350/BTDMJB.20170328092601

Laing, R. D. (2015). Bölünmüş benlik [Self of divided]. Pinhan Yayıncılık.

Lima-Costa, M. F., Firmo, J. O. A., Uchôa, E. (2004). The structure of self-rated health among older adults: the Bambuí health and ageing study (BHAS). Revista de Saude Publica, 38(6), 827-834. https://doi.org/10.1590/s0034-89102004000600011

Melo, A. C. F., Nakatani, A. Y. K., Pereira, L. V., Menezes, R. L., Pagotto, V. (2017). Prevalência de doenças musculoesqueléticas autorreferidas segundo variáveis demográficas e de saúde: estudo transversal de idosos de Goiânia/GO [Prevalence of self-reported musculoskeletal diseases by demographic and health variables: cross-sectional study of elderly of Goiânia/GO]. Cadernos Saude Coletiva, 25(2), 138143. http://dx.doi.org/10.1590/1414-462x201700010274

Öz, F. (2004). Sağlık Alanında Temel Kavramlar [Basic Concepts in the Field of Health]. Ankara: İmaj İç ve Diş Ticaret AŞ, 12.

Özdelikara, A., Agaçdiken-Alkan, S., Mumcu, N. (2018). Determination of health perception, health anxiety and effecting factors among nursing students. The Medical Journal of Bakırköy / Bakırköy Tıp Dergisi, 14(3), 275-82. https://doi.org/10.5350/BTDMJB.20170310015347

Pagotto, V., Bachion, M. M., Silveira, E. A. (2013). Autoavaliação da saúde por idosos brasileiros: revisão sistemática da literature [Self-assessment of health by older Brazilians: systematic review of the literature]. Revista Panamericana de Salud Publica, 33(4), 302-310. https://doi.org/10.1590/s1020-49892013000400010

Pavão, A. L. B., Werneck, G. L., Campos, M. R. (2013). Autoavaliação do estado de saúde e a associação com fatores sociodemográficos, hábitos de vida e morbidade na população: um inquérito nacional [Self-rated health and the association with social 
and demographic factors, health behavior, and morbidity: a national health survey]. Cadernos de Saude Publica, 29(4), 723-734. https://doi.org/10.1590/s0102$\underline{311 \times 2013000800010}$

Pender, N. J., Murdaug, C. L., Parsons, M. A. (2006). Health Promotion in Nursing Practice. (5. eds). Upper Saddle River, NJ: Prentice Hall, 367.

Robichaud, M., \& Dugas, M. J. (2015). The generalized anxiety disorder workbook: A comprehensive cbt guide for coping with uncertainty, worry, and fear. New Harbinger Publications.

Sarıçam, H., Erguvan, F.M., Akın, A. \& Akça, M.Ş. (2014). Belirsizliğe Tahammülsüzlük Ölçeği (BTÖ-12) Türkçe Formu: Geçerlik Ve Güvenirlik Çalışması. [The Turkish Short Version of the Intolerance of Uncertainty (IUS-12) Scale: The Study of Validity and Reliability]. Route Educational and Social Science Journal, 1(3), 148-157. https://doi.org/10.17121/ressjournal.109

Souto, T. S., Ramires, A., Leite, A., Santos, V., Santo, R. E. (2018). Health perception: validation of a scale for the Portuguese population. Trends in Psychology, 26(4), 2185-2201. https://doi.org/10.9788/tp2018.4-17en

Stanley-Budner, N. Y. (1962). Intolerance of ambiguity as a personality variable. Journal of Personality, 30(1), 29-50. https://doi.org/10.1111/j.1467-6494.1962.tb02303.x

Tillet, L. A., \& Pender, N. J. (1998). The health promotion. In Tomey MA, Alligood MR, eds. Nursing Theorist and Their Work. Mosby, St Louis Baltimore, 529-535.

Tuğut N., Bekar M. (2008). Üniversite öğrencilerinin sağlığı algılama durumları ile sağlıklı yaşam biçimi davranışları arasındaki ilişki [Cumhuriyet university student's healthy perception state and the correlation of health promotion life style]. Atatürk Üniversitesi Hemşirelik Yüksekokulu Dergisi 11(3), 17-26.

Ulukan, M. \& Esenkaya, A. (2020). Investigation of the relationship between university students' family harmony and intolerance of uncertainty levels in the COVID 19 process. Academic Social Resources Journal, 5(16), 398-409. http://dx.doi.org/10.31569/ASRJOURNAL.92

World Health Organization (WHO). (2020). Definition of Health. Retrieved from: https:/www.who.int/about/who-we-are/frequently-asked-questions.

Yalnızoğlu-Çaka, S., Topal, S., Karakaya-Suzan, Ö., Çınar, N., Altınkaynak, S. (2017). Hemşirelik öğrencilerin sağlık algısı ile özgüvenleri arasındaki ilişki [The relationship between nursing students' health perception and self-confidence]. Journal of Human Rhythm, 3(4), 199-203.

Yook, K., Kim, K. H., Suh, S. Y. \& Lee, K. S. (2010). Intolerance of uncertainty, worry, and rumination in major depressive disorder and generalised anxiety disorder. Journal of Anxiety Disorders, 24(6), 623-628. https://doi.org/10.1016/j.janxdis.2010.04.003

Zaybak A., Fadıloğlu Ç. (2004). Üniversite öğrencilerinin sağlığı geliştirme davranışı ve bu davranışı etkileyen etmenlerin belirlenmesi [Determining of the health promotion behaviors of university students and the factors affecting these behaviors]. Ege Üniversitesi Hemşirelik Yüksek Okulu Dergisi, 20(1), 77-95. 
Author(s) will retain the copyright of their published articles agreeing that a Creative Commons Attribution 4.0 International License (CC BY 4.0) terms will be applied to their work. Under the terms of this license, no permission is required from the author(s) or publisher for members of the community to copy, distribute, transmit or adapt the article content, providing a proper, prominent and unambiguous attribution to the authors in a manner that makes clear that the materials are being reused under permission of a Creative Commons License. Views, opinions and conclusions expressed in this research article are views, opinions and conclusions of the author(s). Open Access Publishing Group and European Journal of Education Studies shall not be responsible or answerable for any loss, damage or liability caused in relation to/arising out of conflicts of interest, copyright violations and inappropriate or inaccurate use of any kind content related or integrated into the research work. All the published works are meeting the Open Access Publishing requirements and can be freely accessed, shared, modified, distributed and used in educational, commercial and non-commercial purposes under a Creative Commons Attribution 4.0 International License (CC BY 4.0). 